\title{
Impact of trade liberalization and world price changes in Bangladesh: a computable general equilibrium analysis
}

Mohammad Jahangir Alam ${ }^{1,2,3^{*}}$, Jeroen Buysse ${ }^{3}$, Ismat Ara Begum ${ }^{4}$, Stephan Nolte ${ }^{5}$, Eric J. Wailes ${ }^{6}$ and Guido Van Huylenbroeck ${ }^{3}$

* Correspondence: alambau2003@ yahoo.com

${ }^{1}$ Dyson School of Applied Economics and Management, Cornell University, Ithaca 14853NY, USA

${ }^{2}$ Department of Agribusiness and Marketing, Bangladesh Agricultural University, Mymensingh-2202, Bangladesh

Full list of author information is available at the end of the article

\begin{abstract}
The paper analyzes the impact of partial liberalization of trade and changes in world prices of agricultural commodities in Bangladesh using single country Computable General Equilibrium (CGE) model. Since the agricultural sector is sensitive to overall employment, household welfare and food security, the analysis focuses on the changes in agricultural production, consumption, household income and welfare. The results show that trade liberalization increases the welfare of all household groups while world market price increases decrease welfare. It means that although trade liberalization generates a welfare increase for households but this is dependent on the relative level of world commodity prices. Our results are based on the analysis of aggregate household groups, so it may be of future research interest to extend the model with more detailed household groups using a CGE-micro simulation approach.
\end{abstract}

Keywords: Static, CGE, Trade policy, World prices, Agricultural commodities, Bangladesh

\section{Background}

There are many policy debates in Bangladesh whether the country needs to further liberalize its trade, especially after the food commodity price surges during 2007-2008 and the one going on currently, or to go back to a policy of protecting the domestic sectors from foreign competition. Although the country has made much progress in the liberalization of its' trade there is still room to further reduce the protection level. But, the 2007-2008 and the ongoing price surges have initiated the debate especially because the world market supply was found to be unstable making prices more volatile. This may make the country more vulnerable, lead to severe food insecurity both at national and household level, and hence decreases household welfare and could deepened the poverty. It is not unlikely that such price increases happen again in future as a result of the inherent risk in agricultural production, which may be potentially exacerbated by increasing volatility due to climate changes and other relevant factors associated with the commodity price volatility. As the entire population depends on rice for a large share of their calorie intake, food security becomes for the most part analogous to 'rice security'. Therefore, food security and poverty reduction are the top

(C) 2016 Alam et al. Open Access This article is distributed under the terms of the Creative Commons Attribution 4.0 International License (http://creativecommons.org/licenses/by/4.0/), which permits unrestricted use, distribution, and reproduction in any medium, provided you give appropriate credit to the original author(s) and the source, provide a link to the Creative Commons license, and indicate if changes were made. 
priorities of development policy since colonial time in Bangladesh. Several studies (Dorosh 2001; Ivanic and Martin 2007) show that domestic (Bangladesh) market liberalization for inputs and outputs, along with agricultural trade liberalization (import and export) at the border has led to higher productivity, stabilized Bangladesh's overall food security, and reduced real prices of agricultural commodities. But this does not take away the existing concern that an unstable international supply or a distortion in the export policies of major exporting countries can have detrimental effect for a net food importing country such as Bangladesh. Computable General Equilibrium (CGE) model has been used for a very diverse set of policy questions in Bangladesh with results at the macro, sectoral and household level poverty, income and welfare. Marzia (2004) models the effects of trade on women groups differentiated based on the socioeconomic characteristics and has used a gendered social accounting matrix and CGE model for calibrating different trade policy scenarios. The author highlights the role of trade on women and compares the results with Zambia. The main result of this study is that trade liberalization rose female wages and employment in a labour abundant country like Bangladesh but it is not beneficial for women in a natural-resource abundant country like Zambia.

There are very few studies that have evaluated the impact of trade liberalization in the Bangladesh economy such as Annabi et al. (2006), Hoque (2006), Khondker and Raihan (2004), Noman (2002), Ahmed (2001) etc. Most of these studies focused on the macroeconomic perspective rather than distributional aspects such as income, welfare. Khondker and Raihan (2004) presented that full trade liberalization would generate negative consequences for the macro-economy as well as for the welfare and poverty status of the households in Bangladesh. On the contrary, Mujeri and Khondker (2002) found that globalization efforts in Bangladesh are generally pro-poor, although the gains accrue more to the well-off households while the extremely poor households benefit less. Marzia and Adrian (2000) have analyzed the effect of trade on women's wages and jobs, household work and leisure. This paper developed a model with not only the sectors of the market economy but also with social reproduction and leisure activities for men and women separately. The model simulated the effects of changes in trade policies and capital flows on a gender basis. However, the results are very diverse and yield contradiction. Therefore, these diverse results call for a re-examination of the issue. The plausible reasons for the variations of results from different scenarios are the level of sectoral disaggregation, chosen elasticity values, the assumptions made in the factor markets and in the macro constraints. Furthermore, the impact of policies may be different depending on the adjustment path of the economy over time. The contribution of the paper to the large literature are two folds. First, the present study focuses rather disaggregated level household income and welfare in where the experiment of partial liberalization been considered. Our work is different than the existing literature in the sense that the authors in existing literature considered full liberalization and focused mainly at the macro level in where our study considered partial liberalization and focused macro and household level consequences. Second, our study simulated the world price changes to quantity the impacts also at the income and welfare of different households in Bangladesh and compared both the scenarios. To our knowledge, there is no study quantified the commodity price shock using computable general equilibrium model in the case of Bangladesh, although there are few studies that examined 
the impact of world prices changes in Mozambique, Uganda etc. (Arndt et. al. 2008; Benson et al. 2008). So, the present study is also an attempt to fill this gap.

Given this backdrop our aim is to estimate the impact of freer trade and of world food commodity price increases using a single country CGE model. So, our research questions are -what are the consequences of further trade liberalization (50\% tariff-cut for all imported commodities) and world agricultural commodity prices changes (25\% increases of world market prices of import food commodities) on the macro (GDP, imports, exports, investment, government consumption, private consumption), sectoral (focus on rice sectors, activity output, output price, aggregate value-added, factor prices) and household levels (income, consumption and the welfare) in Bangladesh?

The remainder of the paper is organized as follows. Section 2 presents the methodology which is then followed by a brief explanation of the Bangladesh social accounting matrix of 2005, the main features of the database and the elasticity values used for model calibration in section 3. The scenarios, results and the discussions of the study are presented in section 4 . The last section concludes and spots the limitations of the calibrated model and potential improvements for future research. Some complementary Tables are included in the Appendix for the interested readers.

\section{Method}

\section{Computable General Equilibrium (CGE) model}

In this study, the CGE model adopts the core features of the standard IFPRI CGE as described in Lofgren et al. (2002) and the classical trade focused model of Dervis et al. (1982) to calibrate the Bangladesh SAM 2005. A CGE model consists of a set of simultaneous linear and non-linear equations which describe the functioning of an economy. The equations define the behavior of different actors. The equilibrium takes place within a single period and is based on the assumption of competitive Walrassian markets both for commodities and factors of production (Decaluwe and Martens 1988). Key assumptions are (i) producers maximize profits under convex technology; (ii) consumers maximize their utility; (iii) factor payments are at the point where the marginal value product is equal to factor prices; (iv) the model is homogenous of degree zero in prices since only relative prices matter; and (v) output and factor market equilibrium is achieved through adjustment of demand and supply of commodities and factors.

The basic feature of the model is 'neo-classical', but there is unemployment in some factor markets (see the disaggregation of the factor markets presented in Table 1). The model represents a two level nested production technology. At the first level, different intermediate inputs are combined into an aggregate intermediate composite using a Leontief function, and production factors are combined into a value-added composite represented by a CES function. At the second level, the aggregate intermediate and the value-added composites are used as inputs into the production of activity output using a Leontief. The model uses a CES aggregation function to aggregate the output from different activities into a single commodity as the model allows producing one commodity by more than one activity. The produced commodity output has two destinations - domestic sales and/or exports. So, the model adopts imperfect transformation of output into domestic sales and exports based on exporters' revenue maximization behaviour. The Powell-Gruen's (Powell and Gruen 1968) CET function has been used 
Table 1 Model closures or system constraints

\begin{tabular}{|c|c|c|c|}
\hline System constraints & Codes & Closures in factor markets & $\begin{array}{l}\text { Types of } \\
\text { assumptions }\end{array}$ \\
\hline \multicolumn{4}{|l|}{ 1. Micro closures } \\
\hline 1.1 Commodity markets: & C & Endogenous prices clear markets & Neo-classical \\
\hline 1.2 Factor markets: & FACLOS & & \\
\hline $\begin{array}{l}\text { labor } 1 \text { (illiterate } \\
\text { agricultural workers): }\end{array}$ & flab-i & Factor is fully employed \& activity specific in sim & Non neo-classical \\
\hline $\begin{array}{l}\text { labor } 2 \text { (low-skilled } \\
\text { labor): }\end{array}$ & flab-l & Factor is unemployed \& mobile in sim & Non neo-classical \\
\hline $\begin{array}{l}\text { labor } 3 \text { (semi-skilled } \\
\text { labor): }\end{array}$ & flab-s & Factor is unemployed \& mobile in sim & Non neo-classical \\
\hline $\begin{array}{l}\text { labor } 4 \text { (high-skilled } \\
\text { labor): }\end{array}$ & flab-h & Factor is fully employed \& mobile in sim & Neo-classical \\
\hline $\begin{array}{l}\text { capital } 1 \text { (physical } \\
\text { capital): }\end{array}$ & fcap & Factor is fully employed \& activity specific in sim & Non neo-classical \\
\hline $\begin{array}{l}\text { capital } 2 \text { (livestock } \\
\text { capital): }\end{array}$ & fcat & Factor is fully employed \& activity specific in sim & Non neo-classical \\
\hline land (marginal land): & flnd-m & Factor is fully employed \& activity specific in sim & Non neo-classical \\
\hline land (small-scale): & flnd-s & Factor is fully employed \& activity specific in sim & Non neo-classical \\
\hline land (large land): & flnd-I & Factor is fully employed \& activity specific in sim & Non neo-classical \\
\hline \multicolumn{4}{|l|}{ 2. Macro closures } \\
\hline Saving-investment & SICLOS & $\begin{array}{l}\text { Investment fixed \& saving is flexed (so the MPS of all } \\
\text { domestic non-government institutions are flexed at } \\
\text { the base value) (Investment driven) }\end{array}$ & Neo-classical \\
\hline Government balance & GOVCLOS & $\begin{array}{l}\text { Government saving flexed- tax rates fixed } \\
\text { (in ad-valorem)-therefore no scaling in the tax rates } \\
\text { plus government consumption fixed but CPI indexed }\end{array}$ & Neo-classical \\
\hline $\begin{array}{l}\text { Current account balance } \\
\text { (ROW) }\end{array}$ & ROWCLOS & $\begin{array}{l}\text { Foreign saving fixed (in foreign currency) \& } \\
\text { exchange rate flexed }\end{array}$ & Neo-classical \\
\hline
\end{tabular}

here. For non-exported commodities, the total production is absorbed in the domestic market. The commodities available in the domestic market are modeled as a composite supply under the assumption that the import commodities are imperfect substitutes for domestic output following Armington (1969) which is based on the cost minimization behavior of the domestic consumers. All prices are expressed in terms of CPI which is the model numeraire.

In the commodity markets, the composite supply is composed of both domestic production and imported commodities. Demand for each commodity comprises of final private and public demand, investment demand, intermediate input demand and export demand. Final private demand is modeled using a LES derived from the maximization of a Stone-Geary utility function (Blonigen et al. 1997 and Dervis et al. 1982). All other demands (public demand, investment demand and intermediate input demand) are modeled using Leontief equations. The endogenously determined price is the market clearing variable. The equilibrium in the factor market is dependent on how the relationship between factor supply and factor prices (i. e., wage, rent) is determined. Factor markets (except 'labor-high skilled' category) does deviates from neo-classical assumptions. The labor categories: 'low-skilled' and 'semi-skilled' are assumed to be mobile but unemployment exists. The 'labor-illiterate' is assumed to be in full employment but activity specific; two capital (physical and livestock) and three land factors are assumed 
to be fully employed but activity specific. Details of how the nine factor markets are handled in the model are presented in Table 1.

Three macro constraints are formulated as follows. The government account balance (GOVCLOS) - the direct and the indirect taxes of domestic non-government institutions (i. e., different household groups) and the real government consumption are exogenous. So, the government saving is endogenously adjusted. In the current account balance (ROWCLOS) - the foreign saving (which is equivalent to trade deficit) is exogenous in foreign currency and an endogenously determined exchange rate clears the foreign exchange market. The closure is appropriate in the context of the current floating exchange rate policy in Bangladesh. The saving-investment closure (SICLOS) implies that total investment is exogenous and total savings adjust to maintain the saving-investment balance. Although it is heavily debated and controversial in macroeconomics whether CGE models have to be saving or investment adjusted or both (Nell 2003), our Bangladesh model is investment driven model. The details of the micro and macro closures are presented in Table 1.

\section{Equivalent Variation (EV)}

Since trade liberalization and the external price changes directly influence the welfare of households, one of the main interests in this paper is to examine the welfare impacts at household level. The welfare is measured by using some monetary representations 'Money Metric Utility' (Deaton 1980) of the utility function. Anderson and Martin (1996) reviewed the measures of welfare change and conclude that EV dominates other. So, the EV is used as to measure the welfare impacts. The EV measures how much income needs to be given to the households at the pre-policy-change level of prices in order to enjoy the utility level arises after the policy.

For instance, at the base period, the initial commodity price vector is $p^{0}$. Each scenario correspond a new price vector $p^{1}$. A household group with income $Y$ enjoys an initial utility $u^{0}$ at price $p^{0}$ and a new utility $u^{1}$ at new price $p^{1}$. So, the expenditure function $e(p, u)$ is an amount of money that a household group spends in order to achieve $u$ given the price vector $p$. Therefore, EV is defined as follows:

$$
\mathrm{EV}=e\left(p^{0}, u^{1}\right)-e\left(p^{0}, u^{0}\right)
$$

Where, EV represents the net change in welfare that causes the household groups to get the new utility level at base price $p^{O}$. A households group would be better-off if EV is positive and would be worse-off if it is negative.

\section{Experimental scenarios for comparisons}

First is import tariff reduction. The standard trade theory argues in favor of liberalizing trade because it allows countries to specialize in the production of goods for which they have a comparative advantage, allows access to foreign markets, gives access to foreign direct investment, and facilitates technology transfer and marketing networks. It is also argued that trade liberalization reduces poverty. In Bangladesh, during the 1980s and 1990s, the government liberalized and simplified trade, although the country is not obliged to reduce any barriers to trade under the WTO regulations. Bangladesh ranked 8th out of 119 countries across the world for its trade barriers and globalization indices (Raihan 2004). The maximum bound duty is $200 \%$ and the most-favored nations 
applied rate is $25 \%$ (WTO 2009). The un-weighted average protection rate is $13.44 \%$, whereas the weighted average protection rate is $7.59 \%$. Fig. 1 shows the tariff rates of different import commodities. The edible oil, sugar and other food processing sector are highly protected compare to others. Fertilizers, Other cash and yarns are least protected sectors. However, considering the current protection rate and the openness of the economy, we have designed a simulation of a further reduction of the current protection rate (50\% from its base) to examine the welfare impacts at the household level through the commodity and factor markets adjustment in addition to the impacts at the sectoral and macroeconomic performance.

Second one is world price changes of agricultural commodities. This scenario is based on the premise that the implementation of OECD supports policies changes. However, although the extent of world price changes is not clear, a number of world commodity models routinely publish estimates of future trends of agricultural commodity prices. These estimates are based on different assumptions in relation to macroeconomic changes, trade policy changes, and other factors such as agricultural productivity and climate change. To identify feasible price forecasts, we reviewed different forecasting models such as FAPRI, IFPRI, the OECD and the Arkansas Global Rice Model (Cramer et al. 1991). The magnitude of the projected changes varies depending on the model, but the directions of change for most commodities are consistent across the models. So, due to unavailability of consistent numbers (magnitude of the changes) for simulating the expected future commodity price changes-we have postulated a number (25\% price increases) based on the studies of developing countries like Mali (Kofi and Quentin 2008) and Mozambique (Channing et al. 2008) who are also net food importers. Because of projected future climate change, the volatility of production of agricultural commodities would increase if no ameliorating measures are taken. Bangladesh being a net food importing country, it is likely that higher world prices will translate

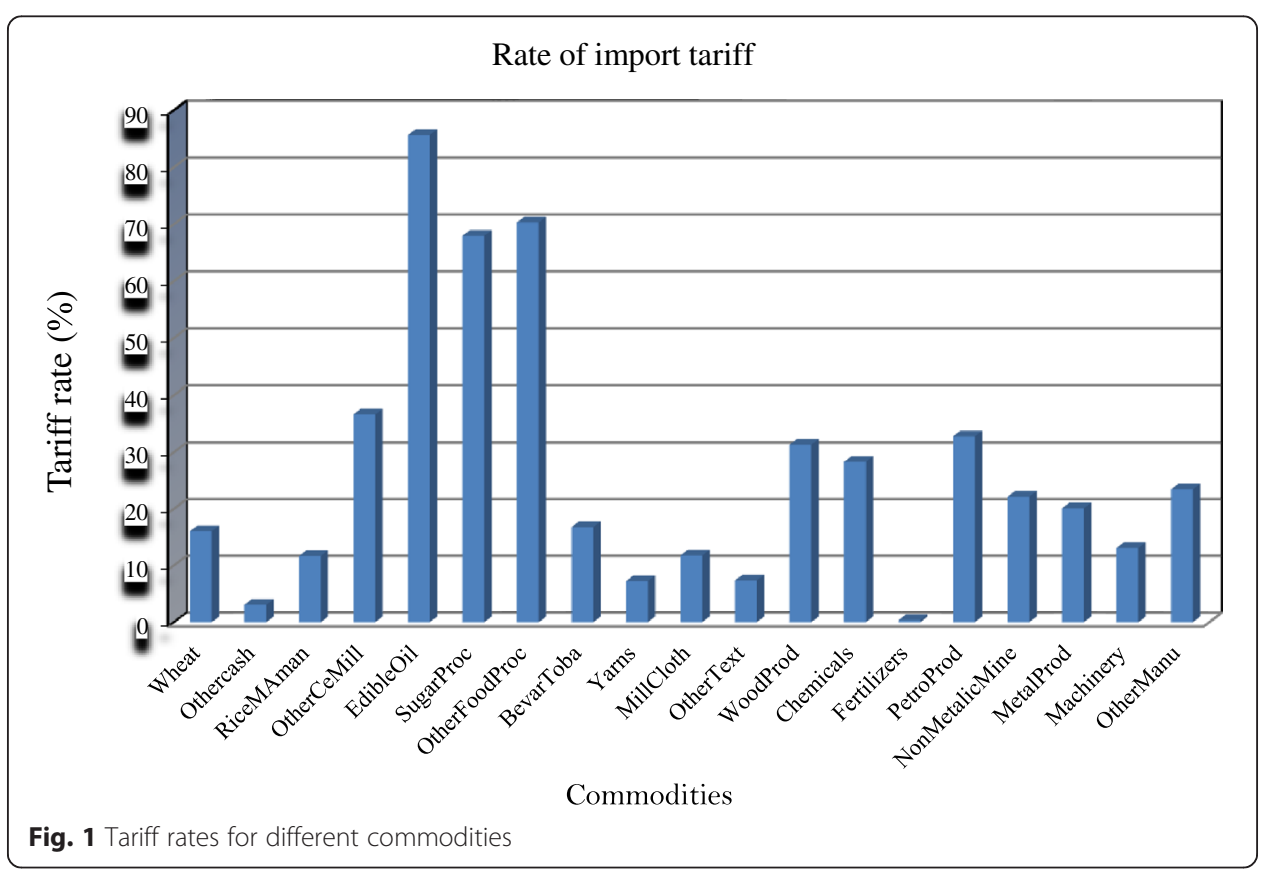


into higher domestic prices, which would have strong implication at the macro, sectoral and household levels.

Farm households in Bangladesh are frequently producers as well as consumers of these imported food commodities. Therefore it is of utmost important to measure the impact of world price changes at the household level, so that policy makers can formulate policies to tackle the situation. It is well known and discussed in literature that the increase of agricultural commodity prices is very likely to have substantial impacts on the farm-households depending on the households' net position whether they are net buyer or net seller (Ivanic and Martin 2007; Wodon et al. 2008; Wodon and Zaman 2008 and World Bank 2008). The CGE analysis performed in this paper goes beyond the analysis in these studies since we are able to investigate economy wide results.

\section{Type of materials used}

\section{The elasticities and parameters}

The model chosen elasticities and parameters found in literature (Marzia 2004). The functions are chosen to reflect the reality of the Bangladesh economy and correspond also to the available elasticity values in literature. The chosen elasticities are (i) Substitution elasticities between factors of production are 0.5 for agricultural and 0.8 for non-agricultural (industry and services) activities. (ii) Trade elasticities of Armington (1969) import and Powell and Gruen (1968) export transformation are 2.0, 1.5 and 0.8 for agricultural, industrial and service commodities respectively for both import and export. (iii) No substitutions between value-added and aggregate intermediate across all production activities. Hence, the substitution elasticities are zero. (iv) The aggregation elasticity which allow for a single commodity to be produced by various activities according to the CES aggregation function, and are 0.5 for agricultural and 0.8 for nonagricultural (industry and services) and (v) The Frisch parameters for different household groups are set based on Dervis et al. (1982) and the authors' own judgment and are presented in Table 2 .

\section{Social accounting matrix of Bangladesh economy}

The present study uses the SAM 2005 constructed by IFPRI (Dorosh and Thurlow 2009) for Bangladesh and this is the latest SAM constructed for Bangladesh economy. The accounts are activity accounts, commodity accounts (one commodity is produced by more than one activity), factors of production, representative households, taxes, core government, saving-investment and the rest of world. A total of 62 activities are specified, of which 23 are agricultural activities (six rice activities), 29 industrial activities

Table 2 Representative households and the Frisch parameters

\begin{tabular}{llc}
\hline Household groups & Definitions & Frisch parameters \\
\hline ha-mf & Marginal agricultural farm households & -3.0 \\
ha-sf & Small-scale agricultural farm households & -3.0 \\
ha-lf & Large-scale agricultural farm households & -5.0 \\
ha-ll & Landless household engaged in agricultural production & -3.0 \\
hn-ls & Non-agricultural households with low-skilled household head & -3.0 \\
hn-ss & Non-agricultural households with semi-skilled household head & -5.0 \\
hn-hs & Non-agricultural households with high-skilled household head & -5.0 \\
\hline
\end{tabular}


and 10 are services activities. The SAM has 59 commodities, disaggregated into 20 agricultural commodities (three rice commodities), 29 industrial commodities and 10 services commodities. The SAM includes nine factors of production, namely, four labor, two capital, and three land. Households are disaggregated into seven different groups based on broadly whether the households receive income from agricultural and non-agricultural activities. Disaggregated households are presented in Table 2. The mapping of micro-SAM is presented in Appendix Table 10.

Labor markets are defined as follows. Labor is separated across four education-based categories such as (i) illiterate agricultural workers whose households still derive incomes from agriculture (farm-laborer families); (ii) low-skilled laborer (primary schooling or less) and illiterate workers whose households derive incomes from wage employment and/or non-farm activities; (iii) semi-skilled labors (some level of secondary schooling); and (iv) high-skilled laborer (have completed secondary schooling and/ or tertiary qualifications).

Agricultural land is disaggregated across three categories: (i) marginal lands (farmhouseholds with less than 0.5 acre of cultivated land); (ii) small-scale lands (households with between 0.5 and 2.5 acres land); and (iii) medium- and large-scale lands (household with more than 2.5 acres land - equivalent to one hectare of land). The two capital accounts are- physical capital and livestock capital.

The model categorizes seven different household groups. First it distinguishes 'agricultural' and 'non-agricultural' households depending on whether the household receives any income from agricultural sector. However, even agricultural households derive at least some of their incomes from non-farm activities and off-farm wage employment; agricultural households are categorized into three land endowment categories such as marginal, small and large. The SAM also identifies households who are landless but derive some of their incomes from working in the agricultural sector. This category is defined as 'landless household engaged in agricultural production'. Finally, non-agricultural households are categorized according to the education level of the household head such as low-skilled, semi-skilled and high-skilled.

\section{Main features of the Business-as-Usual (BaU) scenario}

The salient features of the BaU case of the Bangladesh economy are presented in Table 3. It shows the value-added share, production share, employment share and import-export share. The contribution of agriculture in total value-added is 20.17 $\%$ in which various types of rice account for $6.61 \%$. Out of agricultural value-added, the contribution of rice is very high with about one-third of total agricultural valueadded. The contribution of the industries and service sectors are presented in Appendix Table 11.

The production and employment share of the rice industry in the total agricultural sector is also very substantial (29.02 and $31.39 \%$ respectively) while the share of agricultural export and import is relatively small. The agricultural import share is two times higher than the export share. However, it is likely that world price surges at the world market can be channeled to the household level welfare changes through reallocation of the sectoral production and value-added and through the adjustment in the product and factor markets. 
Table 3 Salient features of the business-as-usual (BaU) scenario

\begin{tabular}{|c|c|c|c|c|c|}
\hline Commodities & VAshr (\%) & PrdShr (\%) & EmpShr (\%) & ExpShr (\%) & ImpShr (\%) \\
\hline Rice & $6.61(32.77)$ & $5.49(29.02)$ & $2.13(31.19)$ & - & - \\
\hline Aus & 0.38 & 0.35 & 0.11 & - & - \\
\hline Aman & 2.63 & 2.05 & 0.93 & - & - \\
\hline Boro & 3.60 & 3.09 & 1.09 & - & - \\
\hline Wheat & 0.22 & 0.22 & 0.12 & - & 1.81 \\
\hline Othercer & 0.11 & 0.1 & 0.05 & 0.00 & 0.19 \\
\hline Jute & 0.48 & 0.50 & 0.33 & - & - \\
\hline Sugar & 0.35 & 0.33 & 0.09 & - & - \\
\hline Othercash & 0.29 & 0.32 & 0.11 & 0.59 & 6.53 \\
\hline Pulse & 0.15 & 0.13 & 0.03 & - & - \\
\hline Rapeseed & 0.11 & 0.09 & 0.02 & - & - \\
\hline Otheroil & 0.11 & 0.1 & 0.02 & 0.0 & 0.83 \\
\hline Spices & 0.59 & 0.56 & 0.13 & 0.02 & 0.11 \\
\hline Potato & 1.16 & 1.01 & 0.21 & - & - \\
\hline Veget & 0.32 & 0.28 & 0.06 & 0.35 & 4.27 \\
\hline Fruits & 0.9 & 0.79 & 0.16 & 0.15 & 0.33 \\
\hline Livestock & 2.43 & 2.24 & 1.46 & 0.02 & 0.05 \\
\hline Poultry & 0.21 & 0.22 & 0.09 & - & 0.04 \\
\hline Shrimp & 1.3 & 1.37 & 0.39 & 4.09 & - \\
\hline Otherfish & 3.03 & 3.14 & 1.17 & 0.5 & 0.03 \\
\hline Forestry & 1.81 & 2.06 & 0.26 & 0.31 & 0.001 \\
\hline Total agri (a) & 20.17 & 18.92 & 6.83 & 6.05 & 14.2 \\
\hline Total non-agric (b) & 79.83 & 81.08 & 93.17 & 93.95 & 85.8 \\
\hline Total $(a+b)$ & 100 & 100 & 100 & 100 & 100 \\
\hline
\end{tabular}

Source: Own calculation from Bangladesh SAM, 2005

Notes: VAshr value added share, PRDshr production share, EMPshr share in total employment, EXPshr sector share in total export, and IMPshr sector share in total imports

Because any policy or exogenous shocks will be transmitted to the household level through the factor markets, it is necessary to examine the initial distribution of the household incomes from different sources. Table 4 shows the distribution of household income from different factor markets. Irrespective of the households' categories-the factor income represents the largest source of household income for

Table 4 Household income sources from factor markets, government \& ROW (\% of total)

\begin{tabular}{llllllllllllll}
\hline HHs & flab-i & flab-l & flab-s & flab-h & fcap & fcat & flnd-m & flnd-s & flnd-l & Total & Gov & Row & Total \\
\hline ha-mf & 20.67 & 9.72 & 12.19 & 3.51 & 26.16 & 3.44 & 9.92 & - & - & 85.61 & 5.87 & 8.52 & 100 \\
ha-sf & 7.92 & 5.91 & 10.26 & 6.71 & 36.58 & 2.9 & - & 17.87 & - & 88.15 & 1.72 & 10.14 & 100 \\
ha-If & 0.87 & 1.62 & 9.46 & 11.69 & 43.52 & 1.93 & - & - & 23.62 & 92.17 & 0.84 & 6.46 & 100 \\
ha-II & 50.68 & 11.31 & 8.37 & 0.91 & 16.90 & - & - & - & - & 88.17 & 6.95 & 4.88 & 100 \\
hn-Is & 37.45 & 22.12 & 2.27 & 0.31 & 28.31 & - & - & - & - & 90.46 & 6.94 & 2.59 & 100 \\
hn-ss & 1.25 & 4.01 & 56.06 & 0.71 & 32.81 & - & - & - & - & 94.84 & 1.47 & 3.69 & 100 \\
hn-hs & - & - & 3.67 & 45.91 & 47.05 & - & - & - & - & 96.63 & - & 3.37 & 100 \\
Total & 14.82 & 7.53 & 13.70 & 9.39 & 34.33 & 1.4 & 0.91 & 4.67 & 4.02 & 90.77 & 3.01 & 6.22 & 100 \\
\hline
\end{tabular}

Source: Own calculation from Bangladesh SAM, 2005 
all household categories, with a range from 85.61-96.63\%. Landless households engaged in agriculture and marginal agricultural households earn the lion share of their income from the factor market for 'illiterate-agricultural workers' whereas the non-agricultural households with high-skilled labor earn more than $90 \%$ of their income from the 'high-skill labors' and 'capital markets' as their principle sources of income. Therefore, any policy that can affect factor markets will have direct income, consumption and welfare impacts at the household level. In other words, given the substantial differences in sources of income, it could be expected that trade liberalization and the world price surges will have different income and welfare impacts depending on how factor prices are affected.

\section{Results and discussions}

\section{Macroeconomic impacts}

The macroeconomic impacts of tariff reduction and world agricultural commodity price increases are presented below in Table 5. Although the components of real absorption vary as a function of the chosen closure rules, our results show that real absorption is increased by $0.58 \%$ in the $\mathrm{S} 1$ and it decreases by $1.02 \%$ in the S2. This happens because of the increases of the private consumption in S1 and decreases of it in S2. In the S1, the price of imports decreases, resulting in a decrease in the price of composite commodities relative to the pre-policy scenario, which drives up aggregate private consumption. In S2, higher import prices result in higher commodity prices at the domestic markets which depress total private consumption. These results re-confirm the existing position of farm-households that they are basically 'net buyer' of agricultural commodities for which the prices has increased in Bangladesh, because price increase decreases the total consumption level of the households. It is worth to mention that the investment and government consumption are fixed in our model. Consequently, the increase of private consumption in S1 is an indication of a welfare increase of private consumers (households) while decreases of private consumption in S2 indicates a welfare decrease for this scenario. Aggregate exports increase by 3.23 and $1.44 \%$ respectively both in S1 and S2, while aggregate imports increase in S1 by $2.31 \%$ but decrease in S2 by $2.21 \%$. GDP growth (at factor cost) in S1 is only $0.39 \%$ while it is $-0.22 \%$ in S2. The positive GDP growth accrues because the removal of tariffs led the resources to move from noncompetitive sectors to more competitive sectors. Currently the tariff revenue in

Table 5 Changes in macro indicators (\% change from BaU)

\begin{tabular}{llll}
\hline Macro indicators & BaU & S1 (\%) & S2 (\%) \\
\hline Real absorption ('000 million Taka) (C+I+G) & 3877.38 & 0.58 & -1.02 \\
Real private consumption ('000 million Taka) (C) & 2892.50 & 0.78 & -1.36 \\
Real investment ('000 million Taka) (I) & 777.90 & - & - \\
Real government consumption ('000 million Taka) (G) & 206.98 & - & - \\
Total real export ('000 million Taka) & 613.88 & 3.23 & -2.21 \\
Total real import ('000 million Taka) & 859.51 & 2.31 & 2.75 \\
Tariff revenue (\% of nominal GDP from base) & 4.1 & -45.32 & -0.22 \\
Real GDP at factor cost ('000 million Taka) & 3388.539 & 0.39 & \\
\hline
\end{tabular}


Bangladesh is $52 \%$ of the total government revenue. Total tariff revenue is decreased by $45.32 \%$ in the S1. However, one has to keep in mind the results are based on the static CGE model which has limitation to capture the impact in the longer term. Nevertheless, CGE model is widely used to analyze the trade policy impact at the macro level because of its ability to consistently track the impact of polices and/or external shocks across entire economy, hence CGE analysis has become a mainstay in the trade policy literature (see Lloyd and MaLaren 2004; Hertel and Reimer 2005; Gilbert 2007; Gilbert and Wahl 2002; Polaski et al. 2008).

\section{Sectoral impacts}

The changes of sectoral level production and value-added are presented in Tables 6 and 7 respectively. Out of 62 activities considered in the analysis, agricultural activities in general, and the rice activities in particular are of special interest in this paper. For the sake of brevity, the disaggregated level impacts on industries and services are presented in the Appendix Table 12 for interested readers. It is estimated that in S1 there would be a minor positive impact on the level of output of different rice production activities, the changes ranging from $0.04-0.11 \%$, while there would be a negative impact in the rice production activities in S2 scenario,

Table 6 Activity output and activity prices (\% change from BaU)

\begin{tabular}{|c|c|c|c|c|c|}
\hline \multirow{2}{*}{$\begin{array}{l}\text { Agricultural } \\
\text { activities }\end{array}$} & \multicolumn{3}{|l|}{ Activity output } & \multicolumn{2}{|c|}{ Activity price } \\
\hline & BaU ('000 million Taka) & S1 (\%) & S2 (\%) & $\mathrm{S1}(\%)$ & S2 (\%) \\
\hline Ausloc & 10.861 & 0.09 & -0.20 & 2.90 & -5.06 \\
\hline Aushyv & 13.427 & 0.11 & -0.24 & 2.87 & -5.00 \\
\hline Amanloc & 45.73 & 0.04 & -0.12 & 1.50 & -2.87 \\
\hline Amanhyv & 96.896 & 0.04 & -0.12 & 1.50 & -2.87 \\
\hline Boroloc & 6.398 & 0.10 & -0.22 & 2.93 & -5.12 \\
\hline Borohyv & 208.235 & 0.10 & -0.22 & 2.92 & -5.11 \\
\hline Wheat & 15.348 & -0.37 & 1.38 & -3.85 & 23.42 \\
\hline Othercer & 7.162 & 0.04 & 1.15 & 1.20 & 20.92 \\
\hline Jute & 34.558 & 0.45 & 0.46 & 4.59 & 4.27 \\
\hline Sugar & 22.705 & -0.78 & 0.01 & -16.76 & 0.34 \\
\hline Othercash & 21.923 & 0.14 & 0.93 & 2.29 & 20.02 \\
\hline Pulse & 8.756 & 0.04 & -0.09 & 2.70 & -4.34 \\
\hline Rapeseed & 6.397 & -2.54 & -1.07 & 2.13 & -32.12 \\
\hline Otheroil & 6.600 & -0.01 & 0.43 & 0.40 & 27.61 \\
\hline Spices & 38.572 & 0.06 & -0.01 & 2.75 & -0.21 \\
\hline Potato & 70.443 & 0.03 & -0.10 & 2.01 & -4.51 \\
\hline Veget & 19.319 & 0.05 & 0.30 & 2.79 & 18.62 \\
\hline Fruits & 54.574 & 0.05 & 0.06 & 2.81 & 2.97 \\
\hline Livestock & 155.447 & 0.33 & -0.05 & 3.25 & -0.37 \\
\hline Poultry & 15.227 & 0.38 & 0.08 & 5.70 & 2.78 \\
\hline Shrimp & 94.842 & 0.11 & 0.08 & 1.85 & 2.03 \\
\hline Otherfish & 218.401 & 0.13 & -0.22 & 2.26 & -3.01 \\
\hline Forestry & 142.773 & 0.05 & -0.09 & 2.16 & -3.17 \\
\hline
\end{tabular}


Table 7 Quantity of aggregate value-added (\% change from BaU)

\begin{tabular}{lcrrllrr}
\hline $\begin{array}{l}\text { Agricultural } \\
\text { activities }\end{array}$ & $\begin{array}{l}\text { BaU } \\
\text { ('000 million Taka) }\end{array}$ & S1 (\%) & S2 (\%) & $\begin{array}{l}\text { Agricultural } \\
\text { activities }\end{array}$ & $\begin{array}{l}\text { BaU } \\
\text { ('000 million Taka) }\end{array}$ & S1 (\%) & S2 (\%) \\
\hline Ausloc & 5.544 & 0.09 & -0.20 & Rapeseed & 3.657 & -2.54 & -1.07 \\
Aushyv & 7.336 & 0.11 & -0.23 & Otheroil & 3.754 & -0.01 & 0.43 \\
Amanloc & 28.57 & 0.04 & -0.12 & Spices & 20.079 & 0.06 & -0.01 \\
Amanhyv & 60.472 & 0.04 & -0.12 & Potato & 39.331 & 0.03 & -0.10 \\
Boroloc & 3.602 & 0.10 & -0.21 & Veget & 10.965 & 0.05 & 0.30 \\
Borohyv & 118.308 & 0.10 & -0.22 & Fruits & 30.578 & 0.05 & 0.06 \\
Wheat & 7.447 & -0.37 & 1.38 & Livestock & 82.185 & 0.33 & -0.05 \\
Othercer & 3.631 & 0.04 & 1.15 & Poultry & 7.15 & 0.38 & 0.08 \\
Jute & 16.147 & 0.45 & 0.46 & Shrimp & 44.132 & 0.11 & 0.08 \\
Sugar & 11.727 & -0.78 & 0.01 & Otherfish & 102.747 & 0.13 & -0.22 \\
Othercash & 9.882 & 0.14 & 0.93 & Forestry & 61.321 & 0.05 & -0.09 \\
Pulse & 5.043 & 0.04 & -0.09 & & & & \\
\hline
\end{tabular}

ranging from $0.12-0.24 \%$. Rice output is not affected directly by any of the scenarios since the tariffs for rice are already fully abolished (so no further abolition in S1) and the world market price for rice is not increased in the S2. In S2, an increase of world agricultural commodity prices is designed only for the commodities to be imported in Bangladesh. The positive activity price impacts ranged from $1.50-2.92 \%$ in the case of S1 whereas in S2 the negative activity price impacts ranged from $2.87-5.11 \%$.

The changes in value-added by sectors are presented in Table 7. As expected, S1 results in a reallocation of resources from protected sectors (i, e., wheat) towards unprotected sectors such as rice and others. Although the magnitude of changes is small, the S1 still increases the value-added of rice production activities. The changes in value-added in different industrial and service activities are higher than those in agricultural activities (Appendix Table 13). It is important to mention here that out of 19 protected sectors, only two are agricultural activities. Results of S2 move in the opposite direction. Increases of world agricultural commodity prices decrease the value-added in rice production activities.

\section{Factor market impacts}

Factor market impacts are presented in Table 8. In our model we have assumed that the 'high-skilled labor' (flab-h) is fully employed, and therefore the supply of this labor type is fixed whereas the 'illiterate agricultural workers', two types of capital (fcap, fcat) and three land categories are activity specific but immobile. The other two factor categories ('low-skilled labor' and 'semi-skilled labor') are under unemployment. Since the high-skilled labor is mobile between sectors and supply is fixed, the factor prices (wages) varied economy-wide. Expectedly, in the S1, the wage rate change is positive and is $2.45 \%$ for 'high-skilled labor' category. This wage rate increase for 'high-skilled' labor is a direct result of the assumption of full employment within this wage category. Despite the fact that our scenarios primarily affect the 
Table 8 Factor wage changes (\% change from BaU)

\begin{tabular}{|c|c|c|c|c|c|c|c|c|}
\hline Activities & Scenarios & flab-i & flab-h & fcap & fcat & flnd-m & flnd-s & flnd-I \\
\hline \multirow[t]{2}{*}{ Ausloc } & S1 & 5.68 & 2.45 & 5.68 & - & 5.68 & 5.68 & 5.68 \\
\hline & S2 & -10.25 & -0.88 & -10.25 & - & -10.25 & -10.25 & -10.25 \\
\hline \multirow[t]{2}{*}{ Aushyv } & S1 & 5.31 & 2.45 & 5.31 & - & 5.31 & 5.31 & 5.31 \\
\hline & S2 & -9.55 & -0.88 & -9.55 & - & -9.55 & -9.55 & -9.55 \\
\hline \multirow[t]{2}{*}{ Amanloc } & S1 & 2.00 & 2.45 & 2.00 & - & 2.00 & 2.00 & 2.00 \\
\hline & S2 & -4.74 & -0.88 & -4.74 & - & -4.74 & -4.74 & -4.74 \\
\hline \multirow[t]{2}{*}{ Amanhyv } & S1 & 2.01 & 2.45 & 2.01 & - & 2.01 & 2.01 & 2.01 \\
\hline & S2 & -4.74 & -0.88 & -4.74 & - & -4.74 & -4.74 & -4.74 \\
\hline \multirow[t]{2}{*}{ Boroloc } & S1 & 5.24 & 2.45 & 5.24 & - & 5.24 & 5.24 & 5.24 \\
\hline & S2 & -9.46 & -0.88 & -9.46 & - & -9.46 & -9.46 & -9.46 \\
\hline \multirow[t]{2}{*}{ Borohyv } & S1 & 5.20 & 2.45 & 5.20 & - & 5.20 & 5.20 & 5.20 \\
\hline & S2 & -9.26 & -0.88 & -9.26 & - & -9.26 & -9.26 & -9.26 \\
\hline \multirow[t]{2}{*}{ Wheat } & S1 & -8.35 & 2.45 & -8.35 & - & -8.35 & -8.35 & -8.35 \\
\hline & S2 & 46.37 & -0.88 & 46.37 & - & 46.37 & 46.37 & 46.37 \\
\hline \multirow[t]{2}{*}{ Othercer } & S1 & 1.68 & 2.45 & 1.68 & - & 1.68 & 1.68 & 1.68 \\
\hline & S2 & 39.97 & -0.88 & 39.97 & - & 39.97 & 39.97 & 39.97 \\
\hline \multirow[t]{2}{*}{ Jute } & S1 & 10.02 & 2.45 & 10.02 & - & 10.02 & 10.02 & 10.02 \\
\hline & S2 & 9.47 & -0.88 & 9.47 & - & 9.47 & 9.47 & 9.47 \\
\hline \multirow[t]{2}{*}{ Sugar } & S1 & -30.41 & 2.45 & -30.41 & - & -30.41 & -30.41 & -30.41 \\
\hline & S2 & 0.39 & -0.88 & 0.39 & - & 0.39 & 0.39 & 0.39 \\
\hline \multirow[t]{2}{*}{ Othercash } & S1 & 6.04 & 2.45 & 6.04 & - & 6.04 & 6.04 & 6.04 \\
\hline & S2 & 44.74 & -0.88 & 44.74 & - & 44.74 & 44.74 & 44.74 \\
\hline \multirow[t]{2}{*}{ Pulse } & S1 & 3.92 & 2.45 & 3.92 & - & 3.92 & 3.92 & 3.92 \\
\hline & S2 & -6.92 & -0.88 & -6.92 & - & -6.92 & -6.92 & -6.92 \\
\hline \multirow[t]{2}{*}{ Rapeseed } & S1 & -75.40 & 2.45 & -75.40 & - & -75.40 & -75.40 & -75.40 \\
\hline & S2 & -50.74 & -0.88 & -50.74 & - & -50.74 & -50.74 & -50.74 \\
\hline \multirow[t]{2}{*}{ Otheroil } & S1 & 0.01 & 2.45 & 0.01 & - & 0.01 & 0.01 & 0.01 \\
\hline & S2 & 43.66 & -0.88 & 43.66 & - & 43.66 & 43.66 & 43.66 \\
\hline \multirow[t]{2}{*}{ Spices } & S1 & 4.28 & 2.45 & 4.28 & - & 4.28 & 4.28 & 4.28 \\
\hline & S2 & -0.64 & -0.88 & -0.64 & - & -0.64 & -0.64 & -0.64 \\
\hline \multirow[t]{2}{*}{ Potato } & S1 & 2.88 & 2.45 & 2.88 & - & 2.88 & 2.88 & 2.88 \\
\hline & S2 & -7.38 & -0.88 & -7.38 & - & -7.38 & -7.38 & -7.38 \\
\hline \multirow[t]{2}{*}{ Veget } & S1 & 4.08 & 2.45 & 4.08 & - & 4.08 & 4.08 & 4.08 \\
\hline & S2 & 27.89 & -0.88 & 27.89 & - & 27.89 & 27.89 & 27.89 \\
\hline \multirow[t]{2}{*}{ Fruits } & S1 & 4.16 & 2.45 & 4.16 & - & 4.16 & 4.16 & 4.16 \\
\hline & S2 & 4.44 & -0.88 & 4.44 & - & 4.44 & 4.44 & 4.44 \\
\hline \multirow[t]{2}{*}{ Livestock } & S1 & 8.32 & 2.45 & 8.32 & 8.32 & - & - & - \\
\hline & S2 & -1.30 & -0.88 & -1.30 & -1.30 & - & - & - \\
\hline \multirow[t]{2}{*}{ Poultry } & S1 & 13.09 & 2.45 & 13.09 & 13.09 & - & - & - \\
\hline & S2 & 2.23 & -0.88 & 2.23 & 2.23 & - & - & - \\
\hline Shrimp & S1 & 5.40 & 2.45 & 5.40 & - & 5.40 & 5.40 & 5.40 \\
\hline
\end{tabular}


Table 8 Factor wage changes (\% change from BaU) (Continued)

\begin{tabular}{rrrrrrrrr}
\hline \multirow{2}{*}{ Otherfish } & S2 & 3.08 & -0.88 & 3.08 & - & 3.08 & 3.08 & 3.08 \\
& S1 & 5.24 & 2.45 & 5.24 & - & - & - & - \\
\multirow{3}{*}{ Forestry } & S2 & -7.03 & -0.88 & -7.03 & - & - & - & - \\
& S1 & 4.73 & 2.45 & 4.73 & - & - & - & - \\
& S2 & -7.31 & -0.88 & -7.31 & - & - & - & - \\
\hline
\end{tabular}

agricultural sector, which depend mostly on low-skilled labour, the model shows that there still might be spill-over benefits for people less directly involved in agriculture.

It is worth to mention that the high-skilled labors are primarily employed in the non-agricultural sectors which have the higher protection. But for all other factor categories, the factor prices are activity specific except the two unemployed factors. The result shows that factor prices are changed positively which directly contributes to the increases (Fig. 2) of factor incomes. The factor price increases are related to positive changes in value-added and output level. Under S2, the changes in factor prices are negative. It is expected that world price increases increase domestic production of the affected products, which can increase factor demand and factor prices. However, since the price increases are related to products for which Bangladesh is a net-importer, the real prices of other commodities are depressed and consequently reduce the factor demand, hence real factor prices. It is admitted here that the results can be due to the selected closure rules in the factor markets. There are no changes of factor prices for the low-skilled and semi-skilled labor because the wages are fixed for these factor categories in our model.

The change in factor incomes from S1 generates an adapted efficient allocation of factor resources among the sectoral activities. Standard trade theory advocates that the reallocation of the resources will be to the competitive sector and as a result it will increase the factor demand, hence the changes of factor wages and factor incomes.

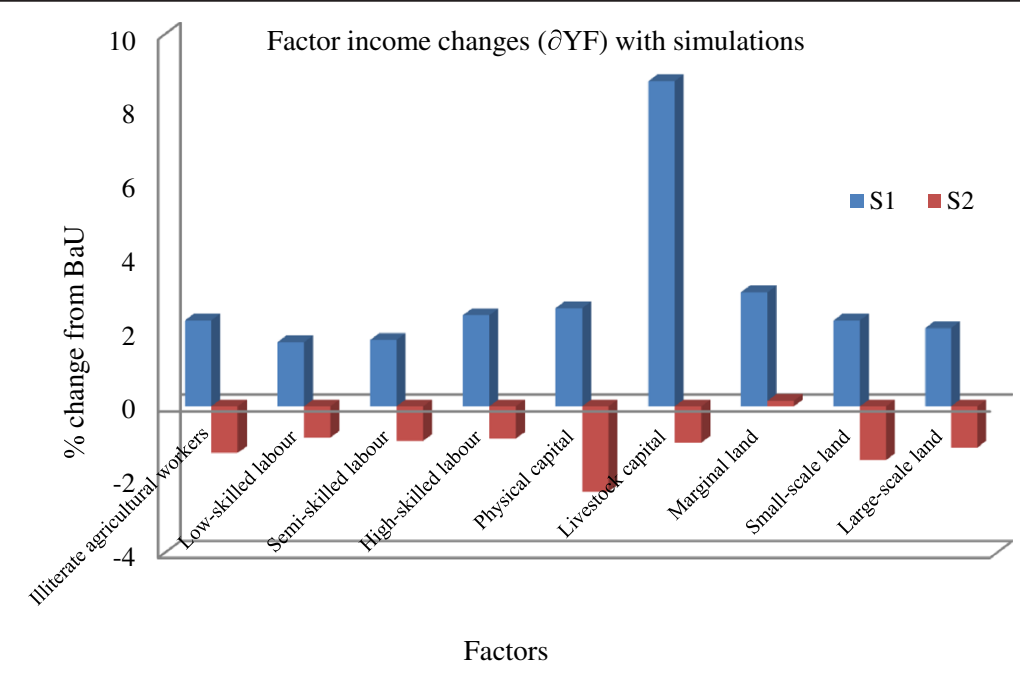

Fig. 2 Factor income changes (\% change from BaU) 
Figure 2 presents the changes of factor income from the S1 and S2. In the S1, the factor income increase significantly but it decreases in the S2.

The income of the factor livestock capital increases more than the income of other factors because it is only used for two activities (livestock and poultry), which price and production increases the most in S1. All other production factors are used for production activities where some of them increase in price and production while others decrease. The fact that this increase in factor income of livestock in $\mathrm{S} 1$ ( $8 \%)$ is higher than the increase in the prices of the products that are produced from this production factor (livestock-3.25\%; poultry-5.70\%), can again be explain by the assumption that some other production factors such as low skilled labour is available in surplus.

\section{Household level impact}

Figure 3 below presents the household income impacts. S1 generates positive income effects for all the households while $\mathrm{S} 2$ generates negative effects. The magnitudes of income increases range between 2.09 and $2.55 \%$. It is very interesting that the calculated income changes in S1 indicate that income inequality would not increase because of the tariff-cut. It is also worth to mention that indeed the factor remunerations are the main source of household income but how the factor prices are determined in the model is mostly dependent on how the factor market closures are defined, so again the results are highly dependent on the closure rules.

Household consumption expenditures and the welfare implications are presented in Table 9. The results indicate that in S1, the consumption growth and the EVs are positive for all household groups while EVs are negative in S2. The positive EV in S1 is the manifestation of positive consumption growth and the negative EV values are associated with negative consumption. The consumption growth and the associated EV values are highest for the 'marginal agricultural farm- households' and 'small-scale agricultural farm households' in S1. The consumption and welfare effects in S1 are channeled through product and factor markets. Because of the tariff-cut, the Bangladeshi households will enjoy cheaper commodities on one hand, and the reallocation of the resources from non-competitive sector to competitive sector that will increase factor demand on the other, and therefore will increase factor prices. So, decreases of prices and increase of household income contribute

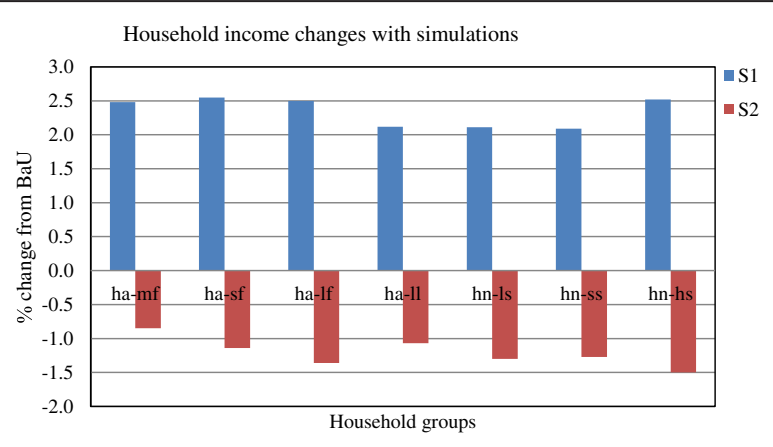

Fig. 3 Household income impacts (\% change from BaU) 
Table 9 Household consumption expenditure and welfare (\% change from BaU)

\begin{tabular}{|c|c|c|c|c|c|}
\hline \multirow{2}{*}{$\begin{array}{l}\text { Household } \\
\text { categories }\end{array}$} & \multirow{2}{*}{$\begin{array}{l}\text { BaU ('000 } \\
\text { million Taka) }\end{array}$} & \multicolumn{2}{|l|}{ S1 } & \multicolumn{2}{|l|}{ S2 } \\
\hline & & Consumption growth (\%) & EV (\%) & Consumption growth (\%-) & EV (\%) \\
\hline ha-mf & 291.92 & 1.05 & 1.1 & -1.06 & -1.0 \\
\hline ha-sf & 772.992 & 0.95 & 1.0 & -1.37 & -1.4 \\
\hline ha-lf & 437.884 & 0.66 & 0.7 & -1.63 & -1.6 \\
\hline ha-II & 329.567 & 0.69 & 0.7 & -1.28 & -1.3 \\
\hline hn-ls & 440.567 & 0.65 & 0.6 & -1.52 & -1.6 \\
\hline hn-ss & 351.741 & 0.48 & 0.2 & -1.51 & -1.0 \\
\hline hn-hs & 267.844 & 0.57 & 0.5 & -1.78 & -1.8 \\
\hline Total & 2892.50 & - & 0.7 & - & -1.4 \\
\hline
\end{tabular}

directly to increases of household consumption. In S2, both the consumption growth and the EVs are negative. Increases of world market price increases the prices of imported commodities, therefore the consumption basket becomes more expensive, which contributes directly to decreases of the consumption and welfare.

\section{Conclusions}

The objective of this paper was to analyze the impact of partial liberalization of trade and the increases of world agricultural commodity prices in Bangladesh using a single-country static CGE model. The results suggest that partial unilateral trade liberalization will have a marginally positive impact on output, value-added, factor wages and hence household income and welfare. Since lots of liberalization efforts have already been undertaken in the past by Bangladesh, it is probable that the bulk of potential benefits from the reduction of protection level are already exhausted. In order to increase welfare of low-income rice producing households, policy maker might want to focus on other complementary policy options at the sectoral level aimed at, for instance, increase productivity or improve market transparency in Bangladesh. The results from our second simulation, world price increases show the opposite.

However, one has to keep in mind the results are based on the static CGE model which has limitation to capture the impact in the longer term. Nevertheless, CGE model is widely used to analyze the trade policy impact at the macro level because of its ability to consistently track the impact of polices and/or external shocks across entire economy, hence CGE analysis has become a mainstay in the trade policy and world price changes literature.

Future research should extend the model in a more sophisticated dynamic framework for evaluating the impacts from medium to longer time period so that capital accumulation, population growth and technological growth can be taken into account in the model specification as well as different elasticity values and different closure rules for investigating the results' sensitivity. Furthermore, the model uses representative household groups which do not take into account heterogeneity among the households within each group. Therefore, it is also a future research interest to overcome the said limitation by extending the model to CGE-micro-simulation. 


\section{Appendix}

Table 10 Mapping of Social Accounting Matrix for Bangladesh Economy, 2005

\begin{tabular}{|c|c|c|c|}
\hline Sectors & Activity code & Commodity code & Description \\
\hline 1 & arausl & cauric & Rice Aus (Local) \\
\hline 2 & araush & & Rice Aus (Hybrid) \\
\hline 3 & aramnl & camric & Rice Aman (Local \& Transplant) \\
\hline 4 & aramnh & & Rice Aman (HYV \& Hybrid) \\
\hline 5 & arborl & cboric & Rice Boro (Local) \\
\hline 6 & arborh & & Rice Boro (HYV \& Hybrid) \\
\hline 7 & awheat & cwheat & Wheat \\
\hline 8 & aocere & cocere & Other Cereals \\
\hline 9 & ajutef & cjutef & Jute \\
\hline 10 & asugar & csugar & Sugarcane \\
\hline 11 & aocash & cocash & Other Cash Crops \\
\hline 12 & apulse & cpulse & Pulses \\
\hline 13 & arapes & crapes & Rapeseed \\
\hline 14 & aooilc & cooilc & Other Oil Crops \\
\hline 15 & aspice & cspice & Spices \\
\hline 16 & apotat & cpotat & Potatoes \\
\hline 17 & aveges & cveges & Vegetables \\
\hline 18 & afruit & cfruit & Fruits \\
\hline 19 & alives & clives & Livestock \\
\hline 20 & apoult & cpoult & Poultry \\
\hline 21 & ashrmp & cshrmp & Shrimp Farming \\
\hline 22 & aofish & cofish & Other Fishing \\
\hline 23 & afores & cfores & Forestry \\
\hline 24 & amines & cmines & Mining and Quarrying \\
\hline 25 & aaumll & caumll & Rice Milling (Aus) \\
\hline 26 & aammll & cammll & Rice Milling (Aman) \\
\hline 27 & abrmll & cbrmll & Rice Milling (Boro) \\
\hline 28 & aocmll & cocmll & Other Cereal Milling \\
\hline 29 & aedoil & cedoil & Edible Oils \\
\hline 30 & asugrp & csugrp & Sugar Processing \\
\hline 31 & aofood & cofood & Other Food Processing \\
\hline 32 & abevtb & cbevtb & Beverages and Tobacco \\
\hline 33 & aleath & cleath & Leather and Footwear \\
\hline 34 & ajtext & cjtext & Jute Textiles \\
\hline 35 & ayarns & cyarns & Yarn \\
\hline 36 & amclth & cmclth & Mill Cloth \\
\hline 37 & aoclth & coclth & Other Cloth \\
\hline 38 & agarms & cgarms & Ready-Made Garments \\
\hline 39 & aknitw & cknitw & Knitwear \\
\hline 40 & aotext & cotext & Other Textiles \\
\hline 41 & awoodp & cwoodp & Wood and Paper \\
\hline 42 & achems & cchems & Chemicals \\
\hline 43 & aferts & cferts & Fertilizers \\
\hline
\end{tabular}


Table 10 Mapping of Social Accounting Matrix for Bangladesh Economy, 2005 (Continued)

\begin{tabular}{llll}
\hline 44 & apetrl & cpetrl & Petroleum Products \\
45 & anmetl & cnmetl & Non-Metallic Minerals \\
46 & cmetal & Metal Products \\
47 & cmachs & Machinery \\
48 & amachs & comanu & Other Manufacturing \\
49 & cconst & Construction \\
50 & aconst & cntgas & Natural Gas \\
51 & antgas & celect & Electricity \\
52 & aelect & cwater & Water \\
53 & awater & ctrade & Retail and Wholesale Trade \\
54 & atrade & chotel & Hotels and Catering \\
55 & ahotel & ctrans & Transport \\
56 & atrans & ccomms & Communications \\
57 & acomms & cbusre & Business and Real Estate \\
58 & abusre & cfsrvs & Financial Services \\
59 & afsrvs & ccsrvs & Community \& Social Services \\
60 & acsrvs & cpadmn & ceduca \\
61 & apadmn & cheals & Public Administration \\
62 & aeduca & aheals & Education \\
\hline
\end{tabular}

Note: Single commodity is producing by more than one activities, that's why the production sectors are 62 but the commodities are 59 
Table 11 Salient features of the business-as-usual (BaU) scenario

\begin{tabular}{|c|c|c|c|c|c|}
\hline Commodities & VAshr (\%) & PrdShr (\%) & EmpShr (\%) & ExpShr (\%) & ImpShr (\%) \\
\hline MinQuary & 1.21 & 0.89 & 1.33 & 0.03 & 1.99 \\
\hline RiceMAus & 0.12 & 0.46 & 0.03 & - & - \\
\hline RiceMAman & 0.78 & 2.75 & 0.23 & 0.04 & 1.88 \\
\hline RiceMBoro & 1.09 & 4.09 & 0.31 & - & - \\
\hline OtherCeMill & 0.1 & 0.58 & 0.05 & 0.08 & 0.23 \\
\hline EdibleOil & 0.35 & 0.75 & 0.21 & 0.01 & 3.69 \\
\hline SugarProc & 0.17 & 0.57 & 0.23 & 0.06 & 1.37 \\
\hline OtherFoodProc & 0.99 & 1.62 & 0.85 & 0.08 & 1.72 \\
\hline BevarToba & 0.26 & 0.28 & 0.13 & 0.01 & 0.02 \\
\hline Leather & 0.21 & 0.59 & 0.17 & 3.78 & 0.42 \\
\hline JuteText & 0.14 & 0.68 & 0.22 & 4.66 & - \\
\hline Yarns & 0.96 & 1.73 & 1.84 & 0.33 & 2.11 \\
\hline MillCloth & 0.73 & 1.07 & 1.25 & 0.75 & 2.05 \\
\hline OtherCloth & 0.67 & 1.12 & 1.03 & 0.32 & 0.76 \\
\hline Garments & 3.32 & 4.88 & 3.42 & 35.73 & - \\
\hline Knitware & 1.69 & 2.21 & 0.38 & 24.49 & - \\
\hline OtherText & 0.17 & 0.24 & 0.32 & 1.97 & 2.36 \\
\hline WoodProd & 0.98 & 1.51 & 1.38 & 0.51 & 2.19 \\
\hline Chemicals & 0.57 & 0.87 & 0.41 & 1.78 & 9.91 \\
\hline Fertilizers & 0.13 & 0.35 & 0.14 & 0.43 & 1.93 \\
\hline PetroProd & 0.05 & 0.06 & 0.02 & - & 8.27 \\
\hline NonMetalicMine & 0.66 & 0.9 & 0.57 & - & 0.36 \\
\hline MetalProd & 0.88 & 1.66 & 1.34 & - & 5.90 \\
\hline Machinery & 0.17 & 0.26 & 0.16 & 2.26 & 24.27 \\
\hline OtherManu & 0.57 & 0.65 & 0.63 & 0.56 & 0.7 \\
\hline Construction & 10.63 & 11.48 & 8.76 & - & - \\
\hline NaturGas & 0.11 & 0.57 & 0.12 & - & - \\
\hline Electricity & 1.52 & 1.01 & 0.36 & - & - \\
\hline Water & 0.1 & 0.07 & 0.03 & - & - \\
\hline ReWholeTrad & 12.7 & 10.04 & 16.06 & - & - \\
\hline Hotel & 0.52 & 0.85 & 0.69 & 6.51 & 8.97 \\
\hline Transport & 9.38 & 7.31 & 12.2 & 1.55 & 1.32 \\
\hline Communi & 1.17 & 0.73 & 1.29 & - & - \\
\hline BussRealEst & 7.53 & 5.18 & 5.13 & - & - \\
\hline FinServices & 1.95 & 1.59 & 3.4 & 8.0 & 3.41 \\
\hline CommuSocSer & 9.57 & 5.31 & 17.56 & - & - \\
\hline PublicAdmin & 2.85 & 2.05 & 4.69 & - & - \\
\hline Education & 2.62 & 1.89 & 4.81 & - & - \\
\hline HealthSer & 2.20 & 2.26 & 1.43 & - & - \\
\hline TAgr & 20.17 & 18.92 & 6.83 & 6.05 & 14.2 \\
\hline TNAgr & 79.83 & 81.08 & 93.17 & 93.95 & 85.8 \\
\hline Total & 100 & 100 & 100 & 100 & 100 \\
\hline
\end{tabular}


Table 12 Sectoral activity output and activity prices (\% change from the BaU)

\begin{tabular}{|c|c|c|c|c|c|}
\hline \multirow{2}{*}{$\begin{array}{l}\text { Production } \\
\text { activities }\end{array}$} & \multicolumn{3}{|l|}{ Activity output } & \multicolumn{2}{|c|}{ Activity price } \\
\hline & BaU ('000 million Taka) & S1 (\%) & S2 (\%) & S1 (\%) & S2 (\%) \\
\hline MinQuary & 62.067 & 0.46 & 0.66 & 1.89 & 1.22 \\
\hline RiceMAus & 31.696 & 0.08 & -0.23 & 2.25 & -3.83 \\
\hline RiceMAman & 191.199 & 0.01 & -0.13 & 1.16 & -2.13 \\
\hline RiceMBoro & 283.834 & 0.08 & -0.23 & 2.25 & -3.85 \\
\hline OtherCeMill & 40.156 & 0.20 & -4.22 & -2.84 & 19.07 \\
\hline EdibleOil & 51.974 & -2.76 & -1.18 & -13.24 & 2.98 \\
\hline SugarProc & 39.629 & -0.78 & 0.01 & -9.55 & 0.67 \\
\hline OtherFoodP & 112.234 & -2.39 & -0.96 & -3.81 & 1.96 \\
\hline BevarToba & 19.677 & 0.29 & -1.45 & 1.32 & 0.50 \\
\hline Leather & 40.721 & 2.64 & 3.23 & 2.03 & 2.12 \\
\hline JuteText & 47.488 & 0.48 & 0.74 & 2.69 & 3.36 \\
\hline Yarns & 120.189 & 1.28 & -2.68 & 0.80 & 13.91 \\
\hline MillCloth & 74.681 & 1.81 & -0.72 & 0.51 & 5.10 \\
\hline OtherCloth & 77.471 & 3.32 & 0.01 & 0.75 & 5.66 \\
\hline Garments & 338.913 & 2.98 & 0.37 & 2.01 & 2.94 \\
\hline Knitware & 153.386 & 0.50 & -0.46 & 2.84 & 3.71 \\
\hline OtherText & 16.933 & 8.43 & -8.78 & 1.58 & 4.82 \\
\hline WoodProd & 105.018 & -1.81 & 0.76 & -2.56 & 1.50 \\
\hline Chemicals & 60.223 & -0.82 & 1.21 & -3.03 & 2.41 \\
\hline Fertilizers & 24.072 & 3.35 & 1.80 & -0.84 & 1.83 \\
\hline PetroProd & 3.881 & -2.70 & 0.79 & -7.71 & 2.88 \\
\hline NonMetalicMine & 62.567 & -0.41 & 0.20 & -0.15 & 0.07 \\
\hline MetalProd & 115.283 & -2.24 & 1.41 & -2.38 & 1.67 \\
\hline Machinery & 17.840 & 5.27 & 3.75 & 1.74 & 3.41 \\
\hline OtherManu & 45.077 & -0.35 & 0.49 & -1.14 & 1.46 \\
\hline Construction & 797.428 & 0.11 & -0.15 & 0.18 & -0.16 \\
\hline NaturGas & 39.448 & 0.21 & -0.16 & 1.72 & 1.42 \\
\hline Electricity & 69.947 & 0.27 & -0.30 & 2.63 & -2.31 \\
\hline Water & 4.956 & 0.40 & -0.35 & 2.70 & -1.87 \\
\hline ReWholeTrad & 697.430 & 0.33 & -0.16 & 0.42 & -0.30 \\
\hline Hotel & 59.286 & 3.66 & 2.11 & 1.87 & 2.56 \\
\hline Transport & 507.622 & 0.53 & -0.31 & 0.34 & -0.19 \\
\hline Communi & 50.442 & 0.44 & -0.50 & 1.23 & -0.88 \\
\hline BussRealEst & 359.689 & 0.29 & -0.70 & 1.67 & -2.14 \\
\hline FinServices & 110.504 & 1.95 & 3.71 & 1.43 & 0.24 \\
\hline CommuSocSer & 369.245 & 0.52 & -1.13 & 0.81 & -0.70 \\
\hline PublicAdmin & 142.766 & 0.13 & -0.05 & 0.60 & -0.14 \\
\hline Education & 130.997 & 0.24 & -0.81 & 1.19 & -0.39 \\
\hline HealthSer & 156.894 & 0.30 & -0.69 & 0.81 & -0.78 \\
\hline
\end{tabular}


Table 13 Quantity of aggregate value-added (QVA) (\% change from BaU)

\begin{tabular}{|c|c|c|c|c|c|c|c|}
\hline $\begin{array}{l}\text { Production } \\
\text { activities }\end{array}$ & $\begin{array}{l}\text { BaU ('000 } \\
\text { million Taka) }\end{array}$ & $\begin{array}{l}\text { S1 } \\
\left(\% \partial Q V A_{i}\right)\end{array}$ & $\begin{array}{l}\mathrm{S} 2 \\
\left(\% \partial \mathrm{QV} A_{\mathrm{i}}\right)\end{array}$ & $\begin{array}{l}\text { Production } \\
\text { activities }\end{array}$ & $\begin{array}{l}\text { BaU ('000 } \\
\text { million Taka) }\end{array}$ & $\begin{array}{l}\text { S1 } \\
\left(\% \partial Q \vee A_{i}\right)\end{array}$ & $\begin{array}{l}\mathrm{S} 2 \\
\left(\% \partial Q \mathrm{Q}_{\mathrm{i}}\right)\end{array}$ \\
\hline MinQuary & 41.167 & 0.46 & 0.66 & ReWholeTrad & 430.298 & 0.33 & -0.16 \\
\hline RiceMAus & 3.987 & 0.08 & -0.23 & Hotel & 17.49 & 3.66 & 2.11 \\
\hline RiceMAman & 26.366 & 0.01 & -0.13 & Transport & 317.934 & 0.53 & -0.31 \\
\hline RiceMBoro & 36.993 & 0.08 & -0.23 & Communi & 39.604 & 0.44 & -0.50 \\
\hline OtherCeMill & 3.549 & 0.20 & -4.22 & BussRealEst & 255.168 & 0.29 & -0.7 \\
\hline EdibleOil & 11.856 & -2.76 & -1.18 & FinServices & 65.966 & 1.95 & 3.71 \\
\hline SugarProc & 5.93 & -0.78 & 0.01 & CommuSocSer & 324.447 & 0.52 & -1.13 \\
\hline OtherFoodP & 33.47 & -2.39 & -0.96 & PublicAdmin & 96.44 & 0.13 & -0.05 \\
\hline BevarToba & 8.931 & 0.29 & -1.45 & Education & 88.70 & 0.24 & -0.81 \\
\hline Leather & 7.156 & 2.64 & 3.23 & HealthSer & 74.568 & 0.30 & -0.69 \\
\hline JuteText & 4.894 & 0.48 & 0.74 & & & & \\
\hline Yarns & 32.518 & 1.28 & -2.68 & & & & \\
\hline MillCloth & 24.662 & 1.81 & -0.72 & & & & \\
\hline OtherCloth & 22.552 & 3.32 & 0.01 & & & & \\
\hline Garments & 112.616 & 2.98 & 0.37 & & & & \\
\hline Knitware & 57.352 & 0.5 & -0.46 & & & & \\
\hline OtherText & 5.753 & 8.43 & -8.78 & & & & \\
\hline WoodProd & 33.223 & -1.81 & 0.76 & & & & \\
\hline Chemicals & 19.302 & -0.82 & 1.21 & & & & \\
\hline Fertilizers & 4.241 & 3.35 & 1.8 & & & & \\
\hline PetroProd & 1.655 & -2.7 & 0.79 & & & & \\
\hline NonMetalicMin & 22.412 & -0.41 & 0.2 & & & & \\
\hline MetalProd & 29.859 & -2.24 & 1.41 & & & & \\
\hline Machinery & 5.755 & 5.27 & 3.75 & & & & \\
\hline OtherManu & 19.226 & -0.35 & 0.49 & & & & \\
\hline Construction & 360.107 & 0.11 & -0.15 & & & & \\
\hline NaturGas & 3.803 & 0.21 & -0.16 & & & & \\
\hline Electricity & 51.591 & 0.27 & -0.3 & & & & \\
\hline Water & 3.388 & 0.4 & -0.35 & & & & \\
\hline
\end{tabular}

Competing interests

The authors declare that they have no competing interests.

\section{Authors' contributions}

MJA developed the concept, prepared data for analysis, conducted simulations in GAMS, contributed to the writing of the manuscript, worked on the estimation procedure, provided critical review. IAB worked in the concept development, contributed to the writing of the manuscript, worked on the estimation procedure. JB and SN conducted simulations in GAMS, generated tables and figures. EJW and GVH providedinterpretation and critical review. All authors read and approved the final manuscript.

\section{Author details}

${ }^{1}$ Dyson School of Applied Economics and Management, Cornell University, Ithaca 14853NY, USA. ${ }^{2}$ Department of Agribusiness and Marketing, Bangladesh Agricultural University, Mymensingh-2202, Bangladesh. ${ }^{3}$ Department of Agricultural Economics, Ghent University, 653 Coupure Links, 9000 Ghent, Belgium. ${ }^{4}$ Department of Agricultural Economics, Bangladesh Agricultural University, Mymensingh 2202, Bangladesh. ${ }^{5}$ Department of Agricultural Economics, Ghent University, 653 Coupure Links, 9000 Ghent, Belgium. 'Department of Agricultural Economics and Agribusiness, the University of Arkansas, Fayetteville, AR 72701, USA.

Received: 19 March 2015 Accepted: 12 January 2016

Published online: 22 January 2016 
References

Ahmed N (2001) Trade liberalization in Bangladesh: An Investigation into Trends. The University Press Limited, Dhaka Anderson JE, Martin W (1996) The Welfare Analysis of Fiscal Policy: A Simple Unified Account, Boston College Working Papers in Economics 316. Department of Economics, Boston College, USA

Annabi N, Khondker B, Raihan S, Cockburn J, Decaluwe B (2006) Implications of WTO Agreements and Domestic Trade Policy Reforms for Poverty in Bangladesh: Short run vs long run impacts'. In: Hertel T, Winters LA (eds) Poverty Impacts of a WTO agreemen. World Bank, Washington D.C

Armington PA (1969) A Theory of Demand for Product Distinguished by Place of production. IMF Staff Paper 16(1):159-178

Arndt C, Benfica R, Maximiano N, Nucifora A, Thurlow J (2008) Higher Fuel and Food Prices: Impacts and Responses for Mozambique. Agric Econ 39(supplement):497-511

Benson T, Mugarura S and Wanda K (2008) Impacts in Uganda of Rising Global Food Prices: the Role of Diversified Staples and Limited Price Transmission. Agricultural Economics 39(supplement): 513-24

Blonigen BA, Joseph EF, Kenneth AR (1997) Sector-focused General Equilibrium Modeling. In: Francois JF, Reinert KA (eds) Applied Methods for Trade Policy Analysis: A Handbook. Cambridge University Press, New York

Channing A, Rui B, Nelson M, Antonio MDN, and James TT (2008) Higher Fuel and Food Prices: Economic Impacts and Responses for Mozambique. IFPRI,Washington DC. Discussion Paper 00836

Cramer GL, Wailes EJ, Goroski J, Phillips S (1991) Impact of Liberalizing Trade on the World Rice Market: A Spatial Model including Rice Quality, Arkansas Experiment Station Special Report 153. University of Arkansas, Fayetteville

Deaton A (1980) The Measurement of Welfare. Theory and Practical Applications. Living Standards Measurement Study. Working Paper No. 7. World Bank, Washington D.C

Decaluwe B, Martens A (1988) CGE modeling and Developing Economies: A Concise Empirical Survey of 73 Applications to 26 Countries. J Policy Model 10(4):529-568

Dervis K, Melo JD, Robinson S (1982) General Equilibrium Models for Development Policy. Cambridge University Press, New York

Dorosh PA (2001) Trade Liberalization and National Food Security: Rice Trade Liberalization between Bangladesh and India. World Dev 29(4):673-689

Dorosh P, Thurlow J (2009) A Social Accounting Matrix for Bangladesh. IFPRI, Washington D.C

Gilbert J (2007) Agricultural Trade Reform Under Doha and Poverty in India. UNESCAP, Bangkok

Gilbert J, Wahl T (2002) Applied General Equilibrium Assessment of Trade Liberalization in China. World Economy 25(5):697-731

Hertel T, Reimer J (2005) Predicting the Poverty Impacts of Trade Reform. J Int Trade Econ Develop 14(4):377-405

Hoque SM (2006) A Computable General Equilibrium Model for Bangladesh for Analysis of Policy Reforms. Centre of Policy Studies, Faculty of Business and Economics, Monash University, Melbourne

Ivanic M, Martin W (2007) Food and Fuel Prices: Recent Developments, Macroeconomic Impact, and Policy Responses, IMF., Washington D.C

Khondker BH, Raihan S (2004) Paper presented at the Seventh Annual Global Economic Conference, 17-19 June, 2004. World Bank, Washington DC, Welfare and Poverty Impacts of Policy Reforms in Bangladesh: A General Equilibrium Approach

Kofi N, Quentin W (2008) Impact of Rising Rice Prices and Policy Responses in Mali, Policy Research Working Paper 4739. The World Bank, Washington D.C

Llyod PJ, MacLaren D (2004) Gains and Losses from Regional Trading Agreements: A Survey. Econ Record 80(251):445-97

Lofgren H, Harris RL and Robinson S with the assistance of Moataz El-said and Marcelle T (2002) A Standard Computable General Equilibrium (CGE) Models in GAMS. Microcomputers in Policy Research, Vol. 5. IFPRI, Washington D.C.

Marzia F (2004) Modeling the Effects of Trade on Women at Work and at Home: Comparative Perspectives. Economie Internationale 99:49-80

Marzia F, Adrian W (2000) Modeling the Effect of Trade on Women at Work and at Home. World Dev 28(7):1173-1190

Mujeri M, and B Khondker (2002) Poverty Implications of Trade Liberalization in Bangladesh: A General Equilibrium Approach. Mimeo, Department for International Development (DFID): Dhaka.

Nell K (2003) Long-run Exogeneity between Savings and Investment: Evidence from South Africa. Working Paper 2. Trade and Industrial Policy Strategies, Johannesburg

Noman ANK (2002) The Impact of Foreign Trade Policies and External Shocks on the Agricultural Sector of Bangladesh. Edited by D. Werner and B. Siegfried. Vol. 45, Farming and Rural Systems Economics: Margraf Verlag, Germany

Polaski S, Panda M, Ganesh-Kumar A, McDonald S, Robinson S (2008) The Impact of Changes in Agricultural Prices on Rural and Urban Poverty. Paper presented at the 11th Annual Conference on Global Economic Analysis. Organized by Purdue University and UN-WIDER. Helsinki, Finland

Powell AA, Gruen FHG (1968) The Constant Elasticity of Transformation Production Frontier and Linear Supply Systems. Int Econ Rev 9:315-328

Raihan S, (2004) Trade Barriers in a Global Perspective. University of Manchester, Center on Regulation and Competition. Working Paper, 76. Manchester, UK

Wodon Q, Zaman H (2008) Poverty Impact of Higher Food Prices in Sub-Saharan Africa and Policy Responses. Mimeo, World Bank, Washington D.C

Wodon Q, Tsimpo C, Backiny-Yetna P, Joseph G, Coulombe H (2008) Impact of Higher Food Prices on Poverty in West and Central Africa. Mimeo, World Bank, Washington D.C

World Bank (2008) Addressing the Food Crisis: the Need for Rapid and Coordinated Action. Background Paper for the Finance Ministers Meetings of the Group of Eight. Poverty Reduction and Economic Management Network, Washington D.C

WTO (2009). World Tariff Profile, 2009. World Trade Organization and International Trade Centre, UNCTAD/WTO, Geneva, Switzerland 